\title{
SISTEM PENGOLAHAN AIR ASAM TAMBANG DARI MATERIAL WASTE DAN APLIKASI MODEL ENKAPSULASI PADA BENDUNGAN TSF DI TAMBANG EMAS MARTABE
}

\author{
Latipa Henim $^{1}$ dan Steven Pearce ${ }^{2}$ \\ ${ }^{1} P T$. Agincourt Resources \\ ${ }^{2}$ Mine Environment Management Ltd, UK
}

\begin{abstract}
ABSTRAK
Indonesia adalah negara yang kaya akan sumber daya alam, baik berupa sumber daya alam pulih maupun yang tidak pulih. Industri pertambangan adalah salah satu aktivitas yang bergerak dalam mengolah sumber daya alam yang tidak pulih yang dapat memberikan dampak positif maupun negatif baik dari sisi sosial, ekonomi maupun lingkungan. Air asam tambang adalah salah satu dampak dari industri pertambangan yang harus ditangani secara serius yang terbentuk akibat reaksi mineral sulfida (pirit) dan logam berat yang terpapar ke media air dan udara yang berasal dari batuan yang terbuka pada saat aktivitas penambangan berlangsung. Sejak tahun 2013, tambang emas Martabe telah menerapkan manajemen air asam tambang (AAT) dalam konstruksi bendungan TSF dengan enkapsulasi sederhana yang dirancang dengan dua kategori utama batuan PAF (Potential Acid Forming) dan NAF (Non Acid Forming) sebagai bagian dari material tanggul TSF konstruksi hilir dan juga mengembangkan basis data karakteristik geokimia material waste di lokasi tambang emas Martabe. NAPP (Net Acid Production Potential) adalah metode standar industri yang digunakan untuk menentukan potensi untuk mengoksidasi dan menghasilkan bahan limbah asam, yang nantinya akan ditempatkan di bendungan TSF dengan metode enkapsulasi. Metode ini bertujuan untuk membungkus material sulfida beresiko tinggi yang sedang di tambang di Martabe dengan lapisan penyegel (sealing layer) dengan mengambil keuntungan dari iklim (curah hujan yang tinggi) dan sifat material ROM (run of mine). Konstruksi lapisan penyegelan dan penjadwalan material waste dilakukan dengan pengembangan strategi operasional pengelolaan limbah yang terperinci dan terintegrasi. Monitoring rutin dengan instrument WRSF (Waste Rock Storage Facility) untuk pengukuran oksigen dan juga dari pengukuran kualitas air menunjukkan kalau enkapsulasi material waste pada embakment TSF berhasil mencegah pembentukan air asam tambang.
\end{abstract}

Kata kunci: material waste, air asam tambang, naf, paf, bendungan tailing, model enkapsulasi

\begin{abstract}
Indonesia is a country that is rich in natural resources, both in renewable and non-renewable. The mining industry is one of the activities that is engaged in processing non-renewable natural resources that can have positive and negative impacts both in terms of social, economic and environmental aspects. Acid mine drainage is one of the impacts of the mining industry which must be dealt with seriously which is formed due to the reaction of sulfide minerals (pyrite) and heavy metals which is exposed with water and air from rocks during mining activities.

Since 2013, the Martabe gold mine has implemented mine acid drainage management (AMD) in TSF dam construction with simple encapsulation designed, with two main categories of PAF (Potential Acid Forming) and NAF (Non Acid Forming) rocks as part of construction TSF embankment material downstream and also develop the geochemical characteristics database of waste material at the Martabe gold mine site. NAPP (Net Acid Production Potential) value is an industry standard method to determine the potential to oxidize and produce acid waste materials, which will be placed in the TSF dam by encapsulation model. This method aims to wrap the high risk sulfide material in a mine at Martabe sealing layer to take advantage of both the climate (high
\end{abstract}


rai fall) and material properties of run of mine (ROM). The construction of sealing layer and scheduling of waste is made possible by the development a detailed and integrated operational waste management strategy. Routine monitoring with the WRSF (Waste Rock Storage Facility) instrument for measuring oxygen and also from measurements of water quality shows that the encapsulation of waste material in TSF embankments successfully prevents the formation of acid mine drainage.

Key words: waste materials, acid mine drainage, naf, paf, tailing storage facility, encapsulation model

\section{A. PENDAHULUAN}

Tambang emas Martabe adalah salah satu dari sekian banyak industri pertambangan yang ada di Indonesia, yang terletak di desa Aek Pining, kecamatan Batangtoru kabupaten Tapanuli Selatan, provinsi Sumatera Utara, yang sudah mulai berproduksi sejak pertengahan tahun 2012. Tambang emas Martabe merupakan endapan epitermal sistem sulfidasi tinggi (high sulfidation) yang terdiri dari enam deposit mineral, tiga diantaranya sedang dieksploitasi yaitu Purnama, Barani dan Ramba Joring sementara tiga deposit mineral lainnya yaitu Tor Uluala, Uluala Hulu dan Horas masih dalam tahap pekerjaan eksplorasi dan semuanya berada di luar area hutan lindung. Penambangan emas Martabe merupakan penambangan terbuka (open-cut) dari pit relatif dangkal yang terletak di perbukitan atau punggung bukit yang mengandung mineral.

Tidak bisa dipungkiri kalau kegiatan pertambangan, baik mineral maupun batubara akan berdampak terhadap sosial, ekonomi dan lingkungan. Air asam tambang merupakan salah satu dampak dari industri pertambangan yang terjadi ketika strata geologi yang mengandung sulfida, biasanya pirit, terpapar ke udara atau lingkungan yang mengoksidasi dan kontak dengan air. Proses oksidasi sulfida memiliki potensi untuk melepaskan keasaman, sulfat dan logam beracun atau non logam ke dalam larutan. Air asam tambang juga dapat terbentuk sebagai hasil dari pelarutan mineral sekunder, biasanya sulfat atau hidroksida, yang melepaskan asam dan atau logam lain/ non logam ke dalam larutan, dan ada juga yang terbentuk dari pelarutan batuan induk yang terkait dengan buffer keasaman, misalnya mineral karbonat yang dapat larut untuk meningkatkan salinitas dan melepaskan kalsium, magnesium dan logam lain seperti mangan ke dalam larutan (Pearce dkk.,2013).

Bendungan TSF (tailing storage facility) adalah merupakan bendungan yang dibangun sebagai tempat mengendapkan sedimen dari air sisa pengolahan emas-perak dari pabrik (processing plant). Sejak tahun 2013 tambang emas Martabe telah menerapkan manajemen air asam tambang (AAT) dalam konstruksi bendungan TSF dengan enkapsulasi sederhana yang dirancang dengan dua kategori utama batuan PAF (Potential Acid Forming) dan NAF (Non Acid Forming), sebagai bagian dari material tanggul TSF hilir dengan mengembangkan basis data karakteristik geokimia material waste. Material waste adalah batuan yang tidak mengandung mineral berharga yang melingkupi tubuh bijih yang harus disingkirkan untuk penambangan bijih tersebut. Pengelolaan material waste adalah komponen integral dari banyak operasi pertambangan dan diperlukan proses pengelolaan yang significant untuk memastikan bahwa tujuan lingkungan hidup dan target kepatuhan tercapai.

Batuan NAF (Non acid Forming) adalan batuan yang tidak berpotensi untuk menghasilkan asam dan batuan PAF (Potential Acid Forming) adalah batuan yang berpotensi menghasilkan asam. NAPP (Net Acid Production Potential) adalah metode standar industri yang digunakan untuk menentukan potensi untuk mengoksidasi dan menghasilkan bahan limbah asam. Metode enkapsulasi bertujuan untuk membungkus material sulfida beresiko tinggi yang sedang di tambang di Martabe dengan lapisan penyegel (sealing layer). Lapisan penyegel dibangun dari bahan ROM 
(run of mine) yang lulus spesifikasi yang ditetapkan oleh tim geoteknis untuk memastikan bahwa lapisan tersebut dapat mengurangi masuknya oksigen sebagai hasil dari mempertahankan tingkat kejenuhan yang tinggi. Strategi ini bertujuan untuk mengambil keuntungan dari iklim (curah hujan tropis yang tinggi) dan sifat-sifat bahan limbah ROM yang memiliki kandungan mineral clay yang tinggi karena perubahan mineralisasi dan adanya volume yang signifikan dari clay breccia. Tambang emas Martabe membuka potensi batuan asam atau PAF (potensi pembentukan asam), yang terkait dengan mineralisasi sulfida yang dikenal akan menghasilkan air asam dan kemudian melakukan manajemen, untuk membatasi potensi perairan penambangan yang terkena dampak air selama operasi penambangan dan pasca penutupan tambang.

\section{B. GEOLOGI}

Deposit Martabe terletak pada busur magmatik Sunda - Banda bagian barat dan terbentuk pada batuan porfiri dasit dan kubah andesit serta kompleks diatrem berumur Tersier Akhir dan terletak pada sekuen batuan vulkanik-sediment yang bersisipan dengan batupasir, batulanau, batulempung karbonan serta aliran lava andesit. Martabe berlokasi dekat dengan splay dari sistem patahan Sumatera dan kerangka struktural ini yang memainkan peranan penting dalam formasi cadangan deposit Martabe (Sutopo, 2013).

Stratigrafi Martabe dari tua ke muda diwakili oleh satuan batuan meta sedimen flysch dan sedimen karbonatan dengan sisipan batuan vulkanik dan epiklastik, berumur Carbonaferous-Permian yang digolongkan ke dalam Tapanuli Grup. Satuan batuan ini berbatasan dengan batolit Granit Sibolga dan Uluala Nagodang. Selanjutnya diendapkan satuan batuan konglomerat dan selang seling batu pasir yang memiliki kemiringan bervariasi antara $20-30^{\circ}$ yang menunjukkan gentle folding. Satuan batuan vulkanik formasi angkola, memiliki textur porpiritik-vulkanik andesite dan vulkanik andesit-basaltik yang berumur Miosen tengah. Hubungan satuan batuan sedimen dan vulkanik ini inter-fingering.

Late-tertiary dacite, andesite dome dan diatreme complex yang terdiri dari andesit-dacite flowdome yang menempati bagian tengan dari area Martabe. Diatreme complex, terdiri dari "core" lava koheren dan sub volcanic feeder, dan outer pyroclastic/volcano clastics. Dacite dome dan diatreme complex berkembang di Purnama, sementara serangkaian breksi yang dikontrol oleh struktur berkembang di Ramba Joring, Tor Uluala dan Uluala Hulu. Mineralisasi high grade biasanya dikaitkan dengan breksi tersilisifikasi, sementara untuk low grade dengan andesit vulkanik dan dasit (Hertrijana, J and Petersen, G. 2005).

Zona alterasi di area Martabe dibedakan ke dalam 4 jenis yaitu, massive silica-vuggy silica pada bagian centre, dilanjutkan dengan advance argillic yang didominasi oleh quartz-alunite dan quartzdickite-kaolinite, dan kemudian ke bagian luar ditempati oleh argillic (illite-smectite) dan terakhir merupakan periperal yaitu prophilitic alterasi yang terdiri dari chlorite-calcite dan trace epidote. Pola alterasi ini menunjukkan proses netralisasi progresif larutan hidrotermal asam dari center ke arah luar melalui interaksi dengan batuan dinding, air tanah dan penurunan suhu. Martabe merupakan endapan epitermal sistem sulfidasi tinggi (high sulfidation), yang dicirikan oleh adanya leaching atau pencucian asam sulfat dan perubahan batuan dinding yang sangat ekstrem, yang ditunjukkan oleh tekstur vuggy porfiritik vulkanik dan breksi. Proses ini diyakini merupakan fase awal mineralisasi emas kadar rendah $(<0.5 \mathrm{~g} / \mathrm{t} \mathrm{Au})$.

Perubahan larutan hidrotermal sangat significant di semua endapan di area Martabe, sehingga menyebabkan ada beberapa jenis mineralisasi yang biasanya di kontrol oleh struktur yang dibedakan berdasarkan tekstur dan tipe alterasi serta komposisi larutan hidrotermal sebagai pembawa mineralisasi. Mineralisasi di Barani yang terletak di sebelah tenggara dicirikan oleh urat kuarsa dengan sedikit vuggy silica, di Purnama dicirikan oleh overprinting urat kuarsa dan vuggy silica, sedangkan di Ramba Joring, Tor Uluala dan Uluala Hulu didominasi oleh vuggy silica. 
Sebagian besar mineralisasi di area Martabe dikontrol oleh struktur, kecuali di Purnama juga dipengaruhi oleh stratigrafi.

Sebagai endapan tipe sulfidasi tinggi, material di Martabe baik ore dan waste mengandung sulfida yang cukup tinggi pada semua jenis batuan dan akan meningkat sesuai dengan kedalaman. Sulfida tersebut hadir dalam massa batuan baik sebagai diseminasi maupun mengisi rongga/rekahan/masif vein, biasanya pirit. Semakin tinggi persentasi mineral sulfide pada batuan, maka akan semakin tinggi potensi batuan tersebut untuk menghasilkan asam, yang kalau tidak dikelola akan menghasilkan air asam tambang. Pengelolaan air asam tambang pada material waste dilakukan dengan pendekatan geologi (analisa mineral) untuk masing-masing prospek di area Martabe, dan dilanjutkan dengan tes geokimia untuk mengklasifikasikan material waste berdasarkan tingkat keasamaannya dan kemudian semua material tersebut akan ditempatkan di bendungan TSF dengan mentode enkapsulasi (sealing layers).

Analisa mineralogi yang dilakukan telah mengidentifikasi sulfida primer penghasil asam adalah pirit, asam yang memproduksi mineral alumino-sulfat seperti jarosite dan alunite bersama dengan sulfat yang tidak menghasilkan asam seperti gipsum. Mineral penetral asam telah diidentifikasi seperti kalsit dan ankerit, dan sejumlah besar mineral lempung hadir termasuk kaolinit, dickit, ilit dan smektit tergantung pada tingkat alterasi dengan alterasi argilik yang memiliki kandungan clay tertinggi.

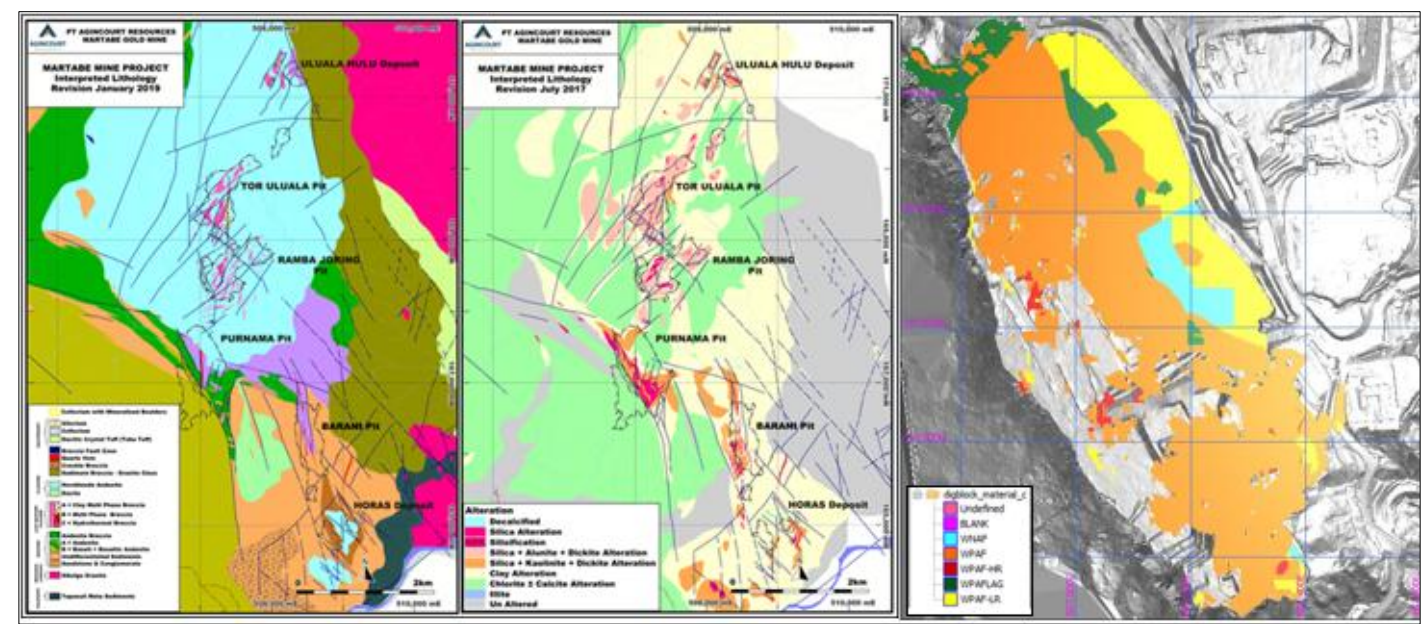

Gambar 1. Peta sebaran batuan dan alterasi (kiri) di Martabe dan sebaran material waste di Purnama (kanan).

\section{PENGUJIAN GEOKIMIA}

ABA (Acid Base Accounting) adalah merupakan salah satu pengujian geokimia yang paling umum yang banyak digunakan untuk memprediksi air asam tambang dari limbah tambang (waste mines). Klasifikasi geokimia material waste melibatakan berbagai teknik ABA, dimana NAPP merupakan standar industri untuk menentukan produksi potensi asam netto (AMIRA 2002). NAPP (Net Acid Production Potential) adalah merupakan perbedaan antara (a) kapasitas netralisasi asam disingkat ANC (Acid Neutralization Capacity), biasanya mewakili kehadiran mineral karbonat yang dapat ditentukan dengan menggunakan metode titrasi dan dinyatakan setara dengan $\mathrm{H}_{2} \mathrm{SO}_{4} / \mathrm{t}$, dan (b) Potensi Keasaman Maksimum yang disingkat dengan MPA (Maximum Potential Acidity) di mana; MPA = wt $\%$ total $\mathrm{S} \times 30,6$ dan dinyatakan setara $\mathrm{kg} \mathrm{H}_{2} \mathrm{SO}_{4} / \mathrm{t}$. Faktor 30.6 merupakan nilai konstanta yang digunakan untuk menghitung nilai MPA ditentukan oleh stoikiometri dan massa molar oksidasi pirit dengan adanya oksigen dan air yang menghasilkan senyawa hidroksida besi. Total sulfur biasanya digunakan untuk perhitungan MPA dengan dengan tidak adanya data spesiasi sulfur, namun kandungan sulfida (sulfur sulfida) juga sering digunakan untuk perhitungan MPA 
karena sulfida dianggap sebagai spesies sulfur pembentuk asam utama. NAPP negatif menunjukkan bahwa sampel memiliki kapasitas netralisasi bersih dan NAPP positif menunjukkan sampel memiliki kapasitas penghasil asam bersih.

$$
\mathrm{NAPP}=\mathrm{MPA}-\mathrm{ANC}
$$

ANC untuk material waste ditentukan dengan mencampur sampel dengan asam klorida yang diketahui berlebih dan titrasi balik asam yang tidak dikonsumsi dengan natrium hidroksida. Pada prinsipnya sebagian besar mineral penertral utama berdasarkan geologi adalah kalsium dan magnesium karbonat dan mineral penetral tambahan yang diperhitungkan dalam penentuan ANC termasuk silikat dasar seperti feldspars kalsik, olivin, amphibol, dan biotit. Namun, karena laju dissolusinya relatif lambat, kontribusi mereka terhadap ANC secara keseluruhan umunya dianggap kecil. Silikat felsic, seperti feldspar sodik dan potasik, muscovite, sebagian besar mineral lempung, dan kuarsa, tidak berkontribusi secara signifikan terhadap ANC.

NAG test merupakan uji lainnya yang digunakan untuk mengklasifikasi jenis batuan yang berpotensi membentuk air asam tambang yang dinyatakan dalam $\mathrm{kg} \mathrm{H}_{2} \mathrm{SO}_{4} /$ ton material. NAG tes dilakukan melalui penambahan $250 \mathrm{~mL}$ hidrogen peroksida $15 \%$ ke dalam 2.5 gram sampel batuan untuk mengoksidasi mineral sulfida yang ada dalam sampel batuan. Campuran peroksida dan sampel dibiarkan bereaksi selama semalam dan pada hari berikutnya campuran tersebut dipanaskan untuk mempercepat reaksi, dan selanjutnya jumlah asam di dalam campuran akan diukur sebagai jumlah bersih dari asam yang timbul. Tes NAG pada prinsipnya didasarkan bahwa zat pengoksidasi kuat (hidrogen peroksida) mempercepat oksidasi dari setiap mineral sulfida. Ketika sampel dioksidasi dan melepaskan keasaman potensial dan disimpan, reaksi netralisasi asam juga terjadi bersamaan. Jika sampel mengandung bahan ANC yang cukup, alkalinitas sampel tidak akan habis dan pH NAG akan bersifat netral terhadap alkali. Jika ANC tidak cukup untuk menetralkan asam yang dilepaskan, pH NAG akan turun di bawah 4,5 dan sampel akan memiliki keasaman bersih positif. NAG tes ini khususnya digunakan untuk mengkonfirmasi prediksi NAPP berdasarkan kandungan sulfur dan nilai ANC.

Paste $\mathrm{PH}$ adalah merupakan tes yang sangat sederhana tetapi dapat memberikan indikasi sifat asam-basa langsung dari sampel. Paste PH dilakukan dengan mencampurkan 1 bagian batuan yang sudah menjadi bubuk $(<75 \mu \mathrm{m})$ dan 2 bagian air deionisasi, diikuti dengan pengukuran Paste $\mathrm{PH}$ sesuai dengan metode AMIRA (2002). Jika pH kurang dari 5.5, itu menunjukkan sampel mengandung keasaman yang tersimpan dalam bentuk produk oksidasi asam seperti mineral jenis melanterit dan jarosit, semakin rendah $\mathrm{pH}$ semakin besar kandungan asam yang disimpan. Sampel yang memiliki paste $\mathrm{pH}$ rendah hampir selalu dianggap berpotensi membentuk asam atau PAF karena reaksi penghasil asam langsung lebih besar daripada reaksi netralisasi asam langsung yang dihasilkan dari mineral yang cepat larut seperti karbonat.

Selain analisa NAPP yang menggunakan nilai MPA dan ANC, diperlukan analisis geokimia tambahan yang lebih terperinci untuk menilai sepenuhnya resiko potensi air asam tambang dan juga diperlukan untuk mengkarakterisasi semua jenis litologi yang significant di semua deposit yang ada di Martabe, seperti pengujian kinetik dan heterogenity.

\section{PROGRAM SAMPLING DAN PENGUJIAN LAPANGAN}

Program sampling (pengambilan sampel) dilakukan secara bertahap di semua deposit yang ada di area Martabe. Pengujian ini bertujuan untuk penentuan klasifikasi material waste, kategori PAF atau NAF. Pemilihan sampel dilakukan dengan menggunakan database geologi hasil kegiatan pemboran, baik itu pemboran eksplorasi, resources development, grade control maupun blast hole dengan menggunakan inti (full coring) ataupun cutting. Sampel-sampel yang dipilih merupakan representatif dari semua jenis litologi, alterasi dan mineralisasi yang ada pada masing-masing deposit yang kemudian akan dianalisa untuk mengetahui parameter asam-basanya. 
Database geologi merupakan kumpulan data hasil analisa sampel yang melekat pada data pemboran yang akan digunakan sebagai acuan untuk penentuan atau pengelompokan material waste, seperti tabel di bawah (tabel 4.1). Sebagian besar analisa sampel akan dilakukan di laboratorium ITS yang ada disite Martabe dan apabila diperlukan sampel juga dikirim ke ITS Jakarta.

Tabel 1. Sulfur data dalam database deposit Purnama.

\begin{tabular}{||c|c|c|c|c|c|c|c|c|c|c|c||}
\hline \hline $\begin{array}{c}\text { S } \\
\text { wt } \%\end{array}$ & $\begin{array}{c}\text { ALL } \\
\text { DATA }\end{array}$ & CBPM & QTZ & SBPM & SED & SOIL & VAN & VANh & VBS & VBX & XFZ \\
\hline $0-0.5$ & $26 \%$ & $15 \%$ & $23 \%$ & $33 \%$ & $5 \%$ & $88 \%$ & $19 \%$ & $33 \%$ & $38 \%$ & $20 \%$ & $15 \%$ \\
\hline $0.5-1$ & $6 \%$ & $9 \%$ & $11 \%$ & $11 \%$ & $4 \%$ & $4 \%$ & $5 \%$ & $14 \%$ & $5 \%$ & $8 \%$ & $14 \%$ \\
\hline $1-2$ & $12 \%$ & $13 \%$ & $14 \%$ & $11 \%$ & $15 \%$ & $3 \%$ & $9 \%$ & $21 \%$ & $10 \%$ & $16 \%$ & $23 \%$ \\
\hline $2-3$ & $16 \%$ & $24 \%$ & $16 \%$ & $20 \%$ & $22 \%$ & $2 \%$ & $16 \%$ & $20 \%$ & $14 \%$ & $18 \%$ & $14 \%$ \\
\hline $3-4$ & $17 \%$ & $28 \%$ & $14 \%$ & $14 \%$ & $20 \%$ & $1 \%$ & $24 \%$ & $7 \%$ & $11 \%$ & $15 \%$ & $12 \%$ \\
\hline $4-5$ & $11 \%$ & $5 \%$ & $9 \%$ & $5 \%$ & $17 \%$ & $0 \%$ & $15 \%$ & $3 \%$ & $9 \%$ & $11 \%$ & $13 \%$ \\
\hline $5-6$ & $5 \%$ & $2 \%$ & $6 \%$ & $4 \%$ & $8 \%$ & $0 \%$ & $5 \%$ & $1 \%$ & $3 \%$ & $7 \%$ & $5 \%$ \\
\hline$>6$ & $6 \%$ & $4 \%$ & $7 \%$ & $3 \%$ & $9 \%$ & $0 \%$ & $6 \%$ & $1 \%$ & $10 \%$ & $6 \%$ & $4 \%$ \\
\hline
\end{tabular}

Tabel 1. Tabel menunjukkan bahwa Soil dan VANh memiliki mayoritas kandungan sulfur yang lebih rendah dan karena itu dapat menurunkan risiko keasaman, tetapi penilaian mineralogi juga diperlukan untuk menentukan apakah sulfur hadir dalam jenis litologi tertentu. (bahan kuning potensial. Buffer tinggi, hijau sedang dan biru rendah), dapat berpotensi membentuk asam (sulfida, atau mineral asam sulfat seperti jarosit) atau membentuk non-asam seperti gypsum.

Pengujian lapangan dengan metode aliran merupakan proses klasifikasi material waste yang dirancang dengan tujuan untuk memamfaatkan tes sederhana yang dapat dilakukan dengan cepat untuk mengurangi penundaan operasi di lapangan. Pada awalnya metode aliran ini dikembangkan dengan menggunakan tiga parameter standar yaitu Paste PH, NAGPH dan NAPP, yang memerlukan waktu lebih kurang satu minggu untuk mendapat hasil analisa dari laboratorium. Untuk meminimalkan keterlambatan operasional, maka metode ABA diganti dengan analisa yang lebih cepat.

Paste $\mathrm{PH}$ adalah merupakan salah satu contoh pengujian lapangan yang sangat sederhana dan cepat dalam penentuan tingkat keasaman material waste, yang diadopsi dari AMIRA 2002. Untuk menggantikan tes NAG maka dilakukan pengujian $\mathrm{PH}$ oksidasi di lapangan yang diambil dari pedoman metode laboratorium ACID Sulfate Soil (Ahern dkk.,2004). Analisa pengujian sampel rutin diterapkan dalam proses penentuan kadar sulfur dan kalsium, disubsitusikan untuk penentuan nilai MPA (maximum potential acidity) dan ANC (acid neutralizing capacity) untuk perhitungan NAPP. Metode aliran ini dibuat untuk menjelaskan pendekatan yang dilakukan dalam klasifikasi geokimia seperti gambar di bawah ini (Pearce, S.2013); 




Gambar 2. Proses metode aliran untuk klasifikasi material waste di Martabe.

Hasil pengujian paste PH dan NAG PH di lapangan, dapat digunakan langsung untuk penentuan klasifikasi material waste tanpa ada modifikasi. Hasil pengujian sebelumnya menunjukkan bahwa data sulfur dan kalsium yang dianalisa dengan menggunakan $x$-ray fluorence portabel (XRF) dan uji rutin data grade control, memberikan proksi yang baik untuk nilai MPA dan ANC (Gambar 2). MPA dihitung dari nilai sulfur yang diamsusikan bahwa semua kalsium hadir merupakan mineral kalsit; 0.4wt\% kalsium kira-kira setara dengan ANC $10 \mathrm{Kg} \mathrm{H} 2 \mathrm{SO} / \mathrm{t}$, NAPP di hitung dari parameter ini.

Semua data kalsium yang ada dalam assay (pengujian mineral logam) data sudah dibandingkan dan untuk pengukuran ANC memberikan indikasi yang baik dengan menggunakan kalsium sebagai pengganti titrasi ANC. Hasilnya seperti Gambar 3 dan menunjukkan trend yang dapat diterima $(\mathrm{R} 2=0.87)$, meskipun ada beberapa outlier yang hadir.

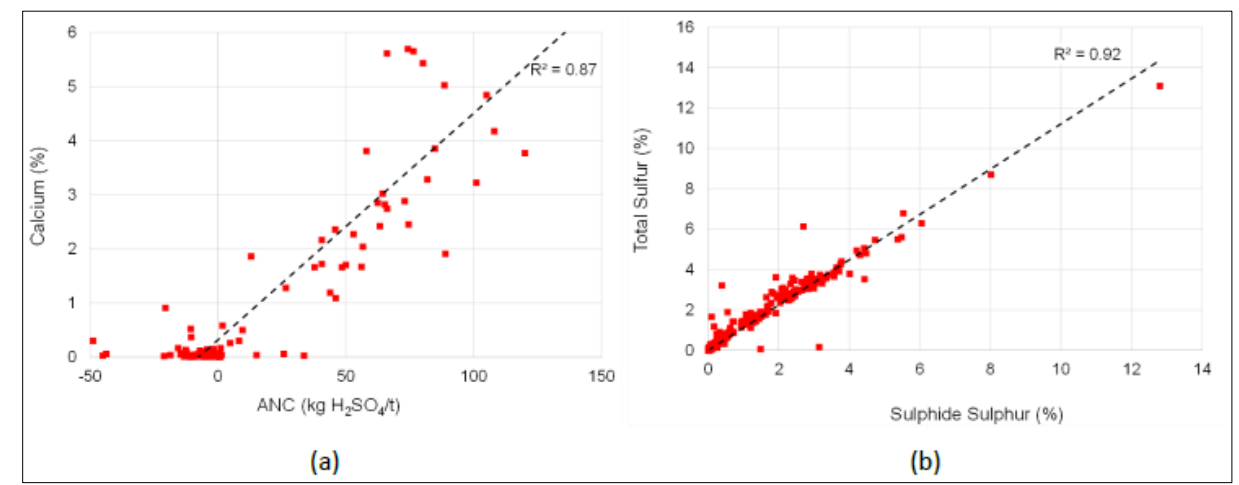

Gambar 3. (a) Total Sulfur vs Sulfide Sulfur (b) ANC vs wt\%Ca.

\section{E. KLASIFIKASI GEOKIMIA DAN PEMODELAN}

Klasifikasi geokimia material waste ke dalam PAF, PAF-low risk, PAF-high risk, PAF-lag dan NAF, dilakukan dengan cara penggabungan atau kombinasi analisa NAPP dengan analisa NAG dan paste PH (Gambar 4). Sistem klasifikasi material waste harus mempertimbangkan karakterisasi batuan, penting untuk penanganan dan pengolahan material waste di bawah strategi rehabilitasi yang dipilih. Di tambang emas Martabe, karakteristik utama ditentukan untuk prediksi resiko AMD, potensi buffering keasaman (kehadiran mineral karbonat seperti kalsit) dan utilitas potensial untuk digunakan dalam konstruksi, dirangkum dalam Tabel 2 (Pearce,S.); 


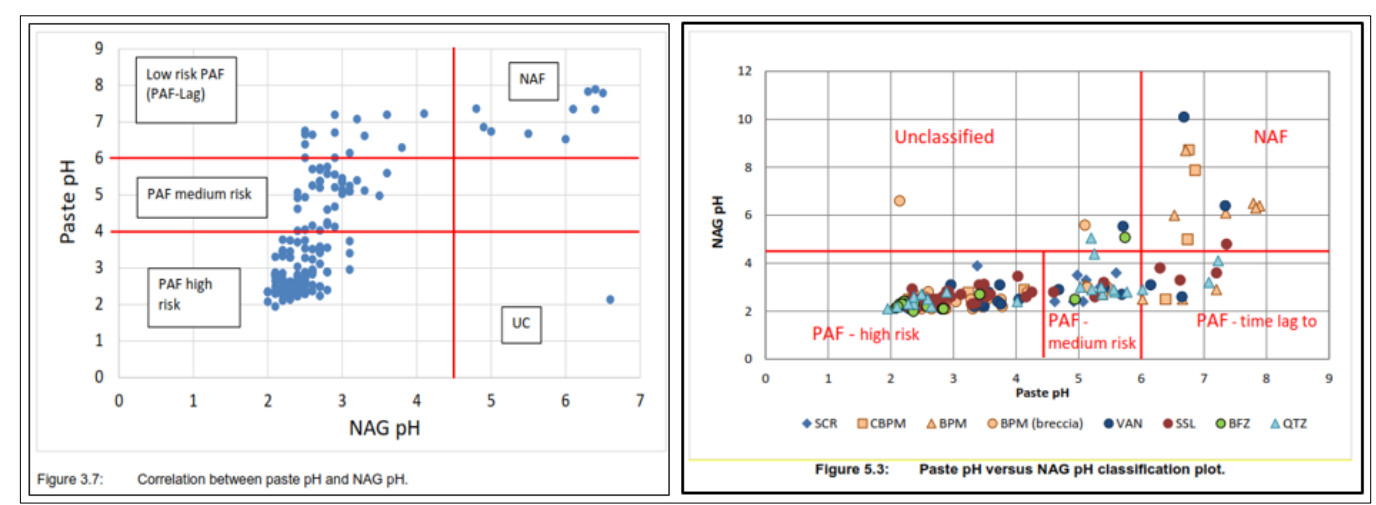

Gambar 4. Grafik korelasi antara paste PH dan NAG pH.

Klasifikasi material waste di Purnama memiliki ciri khas sendiri yang membutuhkan pertimbangan pada saat proses klasifikasi dan pemodelan. Deposit Purnama terdiri dari CBPM (Clay Breccia Phreatomagmatic) yang mengandung banyak clay dan sangat sesuai untuk material sealing layer, tetapi pada kenyataannya dari hasil analisa geokimia sebagian dari CBPM ini juga merupakan material waste kelas 5 atau PAF-LAG yang memiliki kandungan kalsium $>0.4 \%$ (kalsit). Selain CBPM di Purnama juga ditemukan VAN-h (Volcanic Andesite hornblende), pada umumnya blocky dan kompeten merupakan material waste kelas 1 yang sangat cocok untuk konstruksi (Gambar 5).

Tabel 2. Sistem klasifikasi material waste di deposit Purnama.

\begin{tabular}{ccccc}
\hline $\begin{array}{l}\text { Waste } \\
\text { class }\end{array}$ & Name & \multicolumn{3}{c}{ Criteria } \\
\cline { 3 - 5 } & & NAPP $\left(\mathrm{kg} \mathrm{H}_{2} \mathrm{SO}_{4} / \mathrm{t}\right)$ & $\begin{array}{c}\text { Calcium } \\
(\text { wt } \%)\end{array}$ & $\begin{array}{c}\text { Sub-code for } \\
\text { scheduling purposes }\end{array}$ \\
\hline 1 & NAF & $<0$ & Hard/soft \\
\hline 2 & PAF low sulphur & $0-5$ & Hard/soft \\
\hline 3 & PAF medium sulphur & $5-90$ & None \\
\hline 4 & PAF high sulphur & $>90$ & & None \\
\hline 5 & PAF/LAG & $<90$ & $>0.4$ & Hard/soft \\
\hline
\end{tabular}

Berbeda dengan Purnama, dimana sekitar $75 \%$ material waste yang dianalisa memiliki kandungan sulfur total $>0.5 \%$, di Barani hampir setengah dari material waste yang dianalisa memiliki sulfur total kurang dari $0.15 \%$ yaitu pada litology BFZ (Breccia Fault Zone) dan VAN (Volcanic Andesite) dan biasanya juga memiliki kandungan sulfur total yang lebih tinggi, oleh karena itu ke dua jenis batuan ini cenderung memiliki resiko asam yang lebih tinggi. Kandungan kalsium ratarata di Barani untuk sebagian besar sampel yang dianalisa kurang dari $0.15 \%$ yang menunjukkan bahwa kapasitas buffer material di Barani cenderung rendah.

Ramba Joring mirip dengan Purnama, merupakan sistem sulfidasi tinggi yang terdiri dari dua jenis litologi yaitu coherent porpyritic dacite-andesite dan breccia dengan mineralisasi yang berasosiasi dengan silica-alunite dan massive-vuggy silica. Pengujian geokimia yang dilakukan untuk konfirmasi material waste potensi asam (PAF) dan material waste yang tidak berpotensi asam (NAF) sama dengan yang dilakukan terhadap Purnama dan Barani, yaitu dengan pendekatan nilai NAPP. Untuk Ramba Joring sedikit ada keunikan, dengan melimpahnya alunite atau hadirnya natroalunite memberikan dampak yang besar terhadap nilai PHnya, sehingga sering ditemukan hasil analisa geokimia dengan nilai NAPP tidak sesuai dengan yang diperkirakan. Untuk konfirmasi atau validasi tingkat keasaman dan sekaligus kandungan logam di Ramba Joring, maka dilakukan analisa lanjutan yaitu kinetik tes, dimana data ini selanjutnya akan digunakan untuk analisa dan interpretasi untuk pengelolaan ataupun klasifikasi material waste di Ramba Joring. 
Sistem klasifikasi material waste di seluaruh deposit yang ada di martabe di rangkum dalam Tabel 3 ;

Klasifikasi material waste disetiap deposit selanjutnya akan digunakan untuk pemodelan block waste, dengan menggunakan data assay grade control. Penentuan block model ini berdasarkan kriteria AMD dan diberi kode warna sesuai dengan sistem klasifikasinya, dan akan divalidasi dengan cara membandingkan block model waste dari data pemboran grade control dengan block model reserve (cadangan). Terlampir di bawah contoh rekonsiliasi waste block Purnama (Gambar $5)$;

Waste block model ini akan digunakan sebagai acuan penggalian material waste di masing-masing pit sesuai dengan kelasnya dan sebagian besar akan ditempatkan di TSF dengan metode enkapsulasi. Penggalian material waste akan disesuaikan dengan kebutuhan TSF embakment. Penjadwalan peggalian material waste dikembangkan untuk setiap deposit sebelum melakukan penambangan untuk memastikan bahwa rencana penambangan kompatibel dengan rencana pembangunan TSF untuk penyimpanan atau pengelolaan material waste. Praktik operasional pengelolaan limbah yang dikembangkan di lokasi yang mencakup pengeboran grade control terperinci (di pusat $<105 \mathrm{~m}$ ) dan direkonsiliasi dengan model cadangan dianggap mewakili praktik terbaik yang di industri pertambangan.

Tabel 3. Klasifikasi material waste di Martabe.

\begin{tabular}{|c|c|}
\hline Klasifikasi Waste & Deskripsi \\
\hline Kelas 1 & $\begin{array}{l}\text { NAF material utama yang digunakan untuk sealing layer untuk menghambat peningkatan oksigen, } \\
\text { kecuali material dengan ukuran yang terlalu besar, lebih cocok untuk konstruksi dan zona media } \\
\text { growth. Material ini dianggap sebagai bahan beresiko paling rendah dan diharapkan untuk tidak } \\
\text { menghasilkan air asam tambang. Bahan ini harus diperlakukan sebagai sumber daya yang berharga } \\
\text { dan harus dicadangkan untuk konstruksi umum, penempatan dekat dengan kemiringan fasilitas } \\
\text { penyimpanan limbah, untuk lapisan penyegel dan sebagai bagian dari zona media pertumbuhan. } \\
\text { NAPP }<0 \text { dan NAPP }<0 \text { and ALT = Argillic (sealing layer) }\end{array}$ \\
\hline Kelas 2 & $\begin{array}{l}\text { PAF resiko rendah, Bahan PAF low risk, yang tergantung pada ukuran partikelnya juga dapat } \\
\text { digunakan untuk menyegel lapisan atau sebagai bahan pengisi umum dan di zona media pertumbuhan. } \\
\text { Ini termasuk bahan limbah yang memiliki potensi untuk menghasilkan keasaman, tetapi pada tingkat } \\
\text { rendah, sehingga tidak dianggap berisiko tinggi. Bahan ini harus digunakan untuk penempatan di } \\
\text { lereng luar, zona medium pertumbuhan dan untuk menyegel lapisan di mana bahan Kelas } 1 \text { tidak } \\
\text { cukup telah diidentifikasi. NAPP }>0<5 \text { and for sealing layer NAPP }>0<5 \text { and Alt= Argillic }\end{array}$ \\
\hline Kelas 2b & $\begin{array}{l}\text { PAF resiko rendah, yang tergantung pada ukuran partikelnya juga dapat digunakan untuk menyegel } \\
\text { lapisan atau untuk zona } 4 \mathrm{~m} \text { lebih rendah dari zona media pertumbuhan. Ini termasuk bahan limbah } \\
\text { yang memiliki potensi untuk menghasilkan keasaman, tetapi pada tingkat rendah, sehingga tidak } \\
\text { dianggap berisiko tinggi. Bahan ini harus digunakan untuk penempatan di bawah } 4 \mathrm{~m} \text { zona } \\
\text { pertumbuhan media yang ditindih oleh bahan } 4 \mathrm{~m} \text { Kelas } 1+2 \text {. }\end{array}$ \\
\hline Kelas 3 & $\begin{array}{l}\text { PAF, bahan ini yang di yang akan diselimuti (enkapsulasi) dalam tsf embakment. Ini termasuk bahan } \\
\text { yang menghasilkan asam pada tingkat yang mungkin cukup untuk produksi air asam tambang yang } \\
\text { signifikan. Bahan ini memerlukan manajemen di tempat dan enkapsulasi untuk membatasi masulknya } \\
\text { oksigen dan karenanya produksi keasaman berbasis oksidasi pirit. NAPP }>5<90\end{array}$ \\
\hline Kelas 4 & $\begin{array}{l}\text { PAF risiko tinggi yang harus disegel dan dikemas dalam timbunan atau di lokasi pengendapan tailing. } \\
\text { Ini termasuk bahan yang diharapkan menghasilkan jumlah keasaman yang signifikan pada tingkat } \\
\text { yang dapat menimbulkan risiko Air asam tambang yang sangat signifikan. Bahan ini harus dikelola } \\
\text { sebagai prioritas di lokasi dan pertimbangan harus diberikan pada penempatan di luar tanggul } \\
\text { mengingat risiko air asam tambang yang tinggi dari jenis bahan ini. Bahan Kelas } 4 \text { juga termasuk } \\
\text { bahan apa pun dengan } \mathrm{pH} \text { kurang dari } 4 \text {, bahan } \mathrm{pH} \text { rendah ini membutuhkan pengolahan kapur untuk } \\
\text { memastikan } \mathrm{pH} \text { dinaikkan di atas } 4 \text {, laju pengapuran standar } 10 \mathrm{~kg} / \mathrm{t} \text { bubuk kapur terhidrasi telah } \\
\text { ditetapkan untuk di lubang operasi saat ini. NAPP>90 }\end{array}$ \\
\hline Kelas 5 & $\begin{array}{l}\text { Kelas } 5 \text { - Adalah bahan yang mengandung kalsit yang memiliki potensi untuk membentuk keasaman } \\
\text { tetapi juga mengandung kapasitas penyangga yang cukup sehingga produksi keasaman tertunda } \\
\text { secara signifikan, oleh karena itu diperkirakan bahwa ada periode waktu (jeda) yang terbatas sebelum } \\
\text { kondisi asam dihasilkan dari oksidasi ( tidak seperti material Kelas } 3 \text { dan } 4 \text { tanpa waktu untuk } \\
\text { timbulnya asam). Bahan ini diperkirakan menghasilkan rembesan asam (dari sampel curah) setelah } \\
\text { jeda waktu sekitar } 2-5 \text { tahun paparan langsung (bila ditempatkan sebagai lapisan padat setebal } 2 \mathrm{~m} \text { ). } \\
\text { Bahan ini dapat digunakan sebagai lapisan penyegelan sementara, tetapi tidak pada slope luar terakhir } \\
\text { / media pertumbuhan. Drainase dari batuan sisa Kelas } 5 \text { kemungkinan akan menjadi netral dan dapat } \\
\text { memberikan alkalinitas ke batuan sisa yang mendasari yang dapat mengurangi kinetika oksidasi pirit, } \\
\text { atau keasaman buffer yang dihasilkan dalam batuan PAF yang mendasarinya seperti kelas } 3-4 \text {. } \\
\text { Mangan tinggi kemungkinan dihasilkan dari bahan ini sebagai hasil dari pelepasan karbonat. } \\
\text { NAPP>5 }<90 \text {, Calcium }>0.4 \%\end{array}$ \\
\hline
\end{tabular}





Gambar 5. Waste block model di Purnama.

Dua jenis pengujian kinetik telah ditetapkan di lokasi yang digunakan untuk validasi berkelanjutan kriteria klasifikasi waste (limbah) termasuk pengujian konsumsi oksigen yang diselesaikan di laboratorium di lokasi dan metode tangki pencucian yang menggunakan $1 \mathrm{~m} 3$ IBC yang memungkinkan pengujian sampel yang lebih besar $(\sim 1.000 \mathrm{~kg})$ di kondisi insitu.

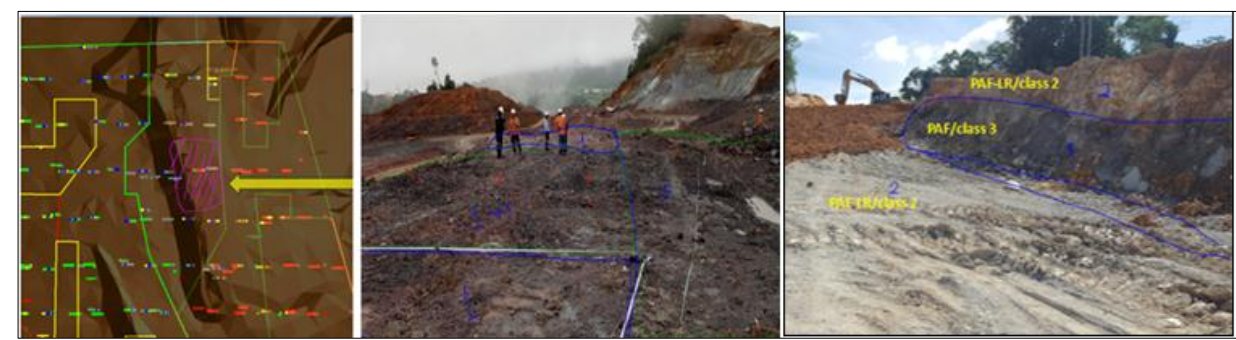

Gambar 6. Contoh material waste berdasarkan klasifikasi geokimia di Purnama.

\section{F. DESAIN PENEMPATAN MATERIAL WASTE DAN METODE ENKAPSULASI}

Aktivitas penempatan material waste merupakan kegiatan harian atau short term yang dijadwalkan dalam rencana penambangan. Adapun tahapan konsep perencanaan jangka pendek sebagai bagian dari kegiatan penambangan, meliputi; pengeboran dan pengambilan sample, pemodelan material waste dan rekonsiliasi, rencana penggalian material waste, pemasangan pita material waste sesuai klasifikasi, pengolahan, pemindahan dan penempatan material waste.

Konsep penempatan material waste pada TSF menggunakan model piggyback struktur internal, ditunjukkan pada Gambar 7, penempatan ini mencakup lift $8 \mathrm{~m}$ PAF (Potensi pembentukan asam) dengan $2 \mathrm{~m}$ solid, bahan bertekstur halus yang ditempatkan di bagian depan, sementara pada permukaan dan belakang dinding material ditempatkan di NAF untuk membentuk lapisan penyegelan (material yang dibungkus kelas 2 dan 3, lapisan pembungkus / penyegelan kelas 1 dan 2 dan penyegelan sementara kelas 5). Prinsip utama dari desain ini adalah untuk mengurangi oksigen dengan mempertahankan tekanan pelapis jenuh menggunakan bahan bertekstur halus yang dimungkinkan oleh iklim yang curah hujan tinggi (tropis). 


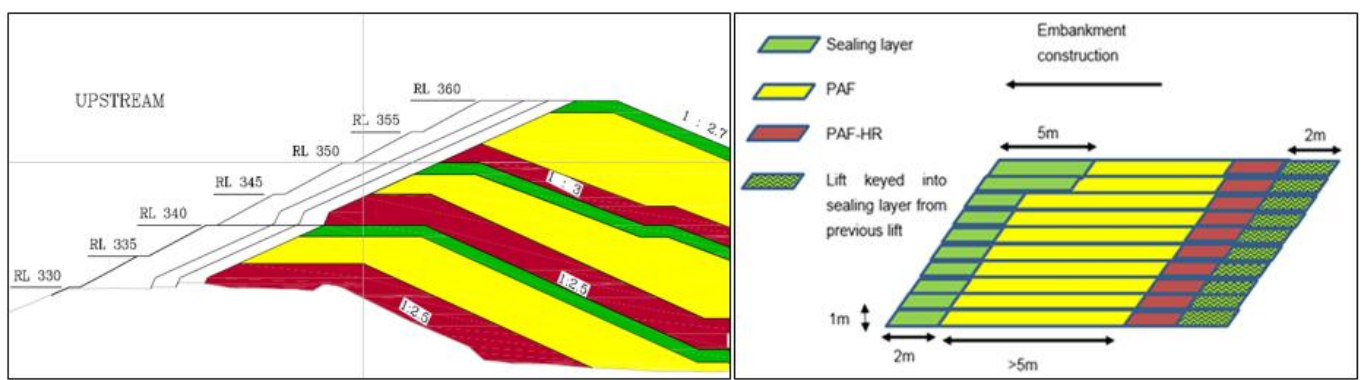

Gambar 7. Struktur internal dari sel Piggyback (enkapsulasi model).

\section{G. MONITORING SEALING LAYER}

Pemantauan TSF adalah bagian dari manajemen AMD yang dilakukan oleh PT. Agincourt Resources dengan tujuan untuk mengkonfirmasi oksidasi sulfida dalam timbunan TSF (fasilitas penyimpanan batuan sisa) setelah penerapan konsep lapisan penyegelan. Pemantauan ini dilakukan dengan pemasangan alat (installing monitoring system) yang bertujuan untuk memantau perubahan suhu, konsentrasi oksigen, tekanan pori air dan potensi matriks. Metode penyegelan lapisan ini bertujuan untuk menghambat atau membatasi produksi dan drainase asam tambang air masuk ke lingkungan sekitar.

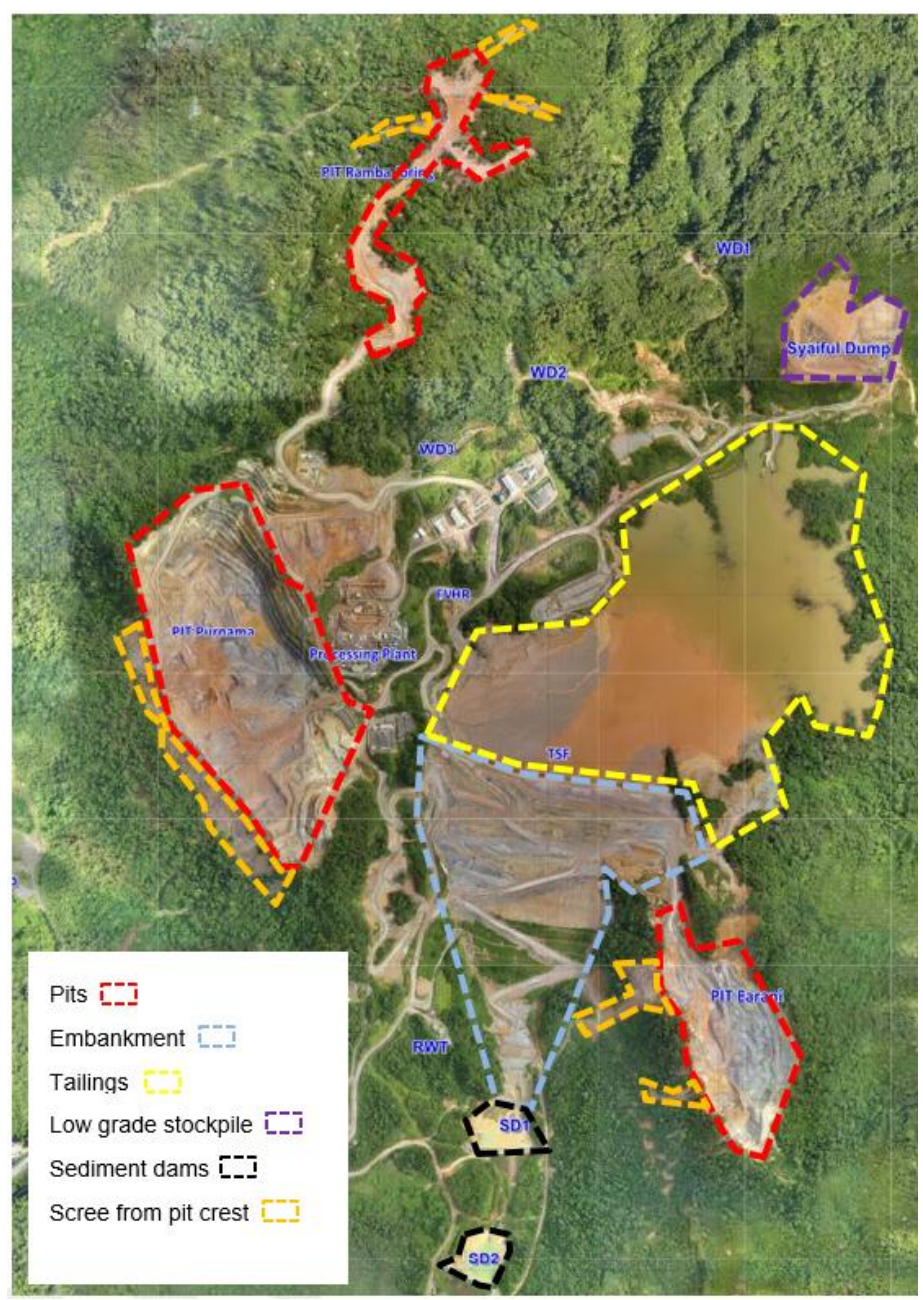

Gambar 8. Martabe site map (2018) 
Data pemantauan pendahuluan menunjukkan bahwa lapisan penyegelan bekerja sesuai dengan konsep dan prediksi pemodelan. Konsentrasi oksigen di dalam dan di bawah lapisan penutup berkurang hingga mendekati nol, dan data pengisapan dan VWC menunjukkan bahan yang mempertahankan tingkat saturasi yang tinggi. Setelah penempatan dan pemindahan bahan tambahan di atas stasiun WRSF (fasilitas penyimpanan batuan sisa), itu menunjukkan hasil positif karena oksigen tetap rendah, dan kondisi kelembaban mencerminkan kadar air yang tinggi (Pearce, S.Etesall. 2017).
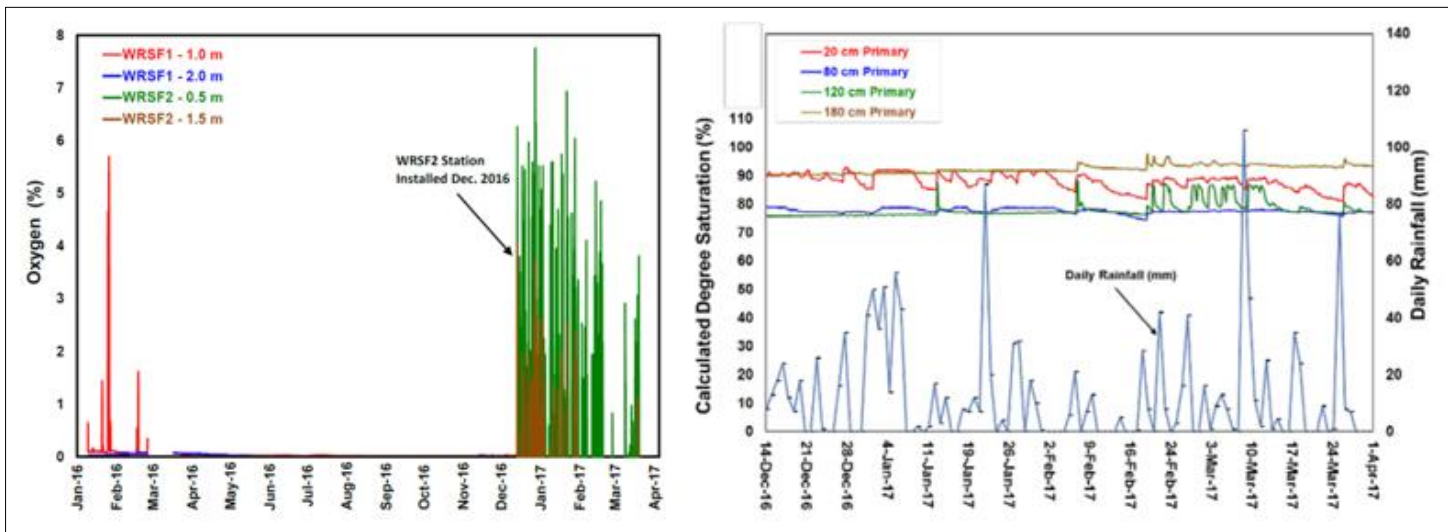

Gambar 9. Konsentrasi Oxygen pada WRSF sealing layer (kiri) dan Perhitungan tingkat kejenuhan material WRSF2.

Gambar 9 menjelaskan hasil pemantauan konsentrasi oksigen dalam lapisan penyegelan TSF embakment (WRSF). Konsentrasi oksigen hampir mendekati 0\% setelah pemasangan WRSF1, sedangkan konsentrasi oksigen di WRSF2 sedikit lebih tinggi pada kedalaman yang dangkal $(<0,5$ m) dengan konsentrasi minimal. Dari pengukuran ini dapat dilihat apakah tekstur dan komposisi bahan memberikan reaksi berbeda selama pengukuran. Pengukuran tingkat kejenuhan material menunjukkan tingkat kejenuhan perhitungan di lokasi pemantauan WRSF2, perhitungan saturasi berdasarkan porositas material dengan pengujian geoteknik dan VWC dari pemantauan insitu, dikategorikan jenuh tinggi karena mereka tetap di atas kira-kira $80 \%$.

\section{H. KESIMPULAN}

Pengelolaan air asam tambang dengan metode enkapsulasi (sealing layer) yang diterapkan oleh PT. Agincourt Resources telah terbukti mampu menghambat atau mencegah terjadinya pengembangan air asam tambang. Metode ini juga telah memberikan manfaat yang besar, selain dampak positif terhadap lingkungan juga telah memberikan mamfaat besar bagi pengenalan mineralisasi batuan untuk masing-masing deposit (study) dan juga menambah kemampuan bendungan TSF untuk menampung endapan air dari Selatan yang tersisa dari pabrik pengolahan yang berlebihan.

Program AMD (Acid mine drainage) akan dilakukan terus menerus dan telah dijadwalkan sampai penutupan tambang dan akan terus dikembangkan dengan penelitian lain, seperti pengujian kinetik dan analisis heterogenitas geokimia batuan sisa tambang. Keberhasilan model enkapsulasi dengan sealing layers, membutuhkan klasifikasifikasi material waste lebih dari detail, sehingga dapat dipakai untuk meningkatkan akurasi model yang sudah ada, untuk peningkatan resources (sumber daya) serta reserve (cadangan).

Praktik pengelolaan operasional material waste dikembangkan di lokasi yang mencakup pengeboran grade control terperinci (di $<105 \mathrm{~m}$ pusat), pengujian validasi komprehensif (> 1000 sampel) dan rekonsiliasi dengan model cadangan dianggap mewakili praktik industri terbaik. 


\section{DAFTAR PUSTAKA}

AMIRA (2002): Prediction and Kinetic Control of Acid Mine Drainage, Amira International Limited, Melbourne ARD Test handbook - Project, P387A.

Harlan, B., Jones, ML., Sutopo, B., Hoschke, T. (2005): Discovery and Characterization of the Martabe Epithermal Deposits, North Sumatra, Indonesia, GSN Symposium 2005.

Hertrijana, J., Petersen, G. (2009); Review on Martabe Gold-Silver Deposits North Sumatra, Indonesia

Lotter Moser, BG. (2003): Mine wastes: Characterization, treatment and environmental impacts, Springer-Verlag, Berlin, p. 277.

Nugraha, G.N., dan dkk,. (2016): Identifikasi Visual Batuan PAF dan NAF, Studi Kasus di PT Arutmin Indonesia Asam asam.

Pearce,S dan Barteaux,. (2014): Instrumentation of waste rock dumps as partof integrated closure monitoring and assessment, in Mine Closure 2014, Proceedings of the Ninth International Conference on Mine Closure, A.B. Fourie and M. Tibbett (eds), Australian Centre for Geomechanics, Brisbane, Australia.

Pearce S., Eds H Miller., Grosh .,K.(2016); Beyond the PAF cell, Workshop on Acid and Metalliferous Drainage, Australia, 15-17 2016, p. 619-635.

Pearce, SR., Warner, J., Sinclair, E., Pearce, J., Olds, W., Weber, P. (2016): A risk-based approach using process flow diagrams for operational waste rock classification-Case studies.

Pearce,SR., Orr, M., Grohs, K., Pearce, J.(2016): Progressive rehabilitation-Martabe Gold Mine, as a case study

Wijaya, R.A.E. (2009): Sistem Pengolahan air asam tambang pada water pond dan aplikasi model encapsulation in-pit waste dump Tambang Batubara, Jurnal Manusia dan Lingkungan. Staff Pengajar Program Studi Teknik Pertambangan, STTNAS Yogyakarta. 
PROSIDING TPT XXVIII PERHAPI 2019 